Diabetologia 8, 296-300 (1972)

(C) by Springer-Verlag 1972

\title{
Presence of Pancreatic Glucagon in the Portal Plasma of Human Neonates. Differences in the Insulin and Glucagon Responses to Glucose Between Normal Infants and Infants from Diabetic Mothers
}

\author{
A. S. LuYckx*, F. Masst-Benedetri, A. Falorni and P. J. Lifferbvre \\ Section of Diabetes. Institute of Medicine, University of Liège, Belgium and Department of Pediatrics, University of \\ Perugia, Italy
}

Received: March 22, 1972, accepted: April 10, 1972

\begin{abstract}
Summary. Human neonates have been studied during the first hours of life. Blood glucose, portal plasma insulin and glucagon have been determined both at regular intervals up to $24 \mathrm{~h}$ after birth and during an intravenous glucose load performed at the 24 th $h$. A material presenting the immunological characteristics of pancreatic glucagon has been found in the portal plasma of both normal infants and infants from diabetic mothers (IDM). The intravenous glucose load did not suppress plasma glucagon in the normal neonates nor in the IDM. Higher portal plasma glucagon values were observed in the late phase of the intravenous glucose load in normal neonates compared to IDM. Portal plasma insulin has been found higher in IDM both at the 24th $h$ of life and during the early phase of the intravenous glucose tolerance test. The hypothesis is put forward that the behaviour difference in glucagon secretion might be a consequence of the relative hyperinsulinism of IDM with insulin facilitating the entry of glucose into the $\alpha$ cell thus permitting a more effective glucagon suppression.
\end{abstract}

Présence de glucagon pancréatique dans le plasma portal de nouveau-nés. Différences de réponses de l'insuline et du glucagon au glucose entre les enfants normaux et les enfants de mères diabétiques.

Résumé. Les auteurs ont étudié des nouveau-nés humains pendant les premières heures de la vie. La glycémie, les taux d'insuline et de glucagon dans le plasma portal ont été dosés à intervalles réguliers jusqu'à la 24 ème heure après la naissance, de même què au cours d'une surcharge glucosée intraveineuse pratiquée à la 24 ème heure. - Un matériel présentant les caractéristiques immunologiques du glucagon pancréatique a été mis en évidence dans le plasma portal des nouveau-nés normaux et de mère diabétique. La surcharge glucosée intraveineuse ne réduit pas le taux de glucagon plasmatique chez le nouveau-né normal ni chez l'enfant de mère diabétique. - Dans la phase tardive de la surcharge glucosée intraveineuse, les valeurs de la glucagonémie portale sont plus élevées chez l'enfant normal que chez le nouveau-né de mère diabétique. L'insulinémie portale est plus élevée chez lo nouveau-né de mère diabétique à la 24 ème heure de la vie et à la phase initiale de la surcharge glucosée. L'hypothèse est proposée que la différence de comportement du glucagon pourrait résulter de l'hyperinsulinisme relatif de l'enfant de mère diabétique, l'insuline favorisant la pénétration de glucose dans la cellule $\alpha$ et permettant, par ce mécanisme, une suppression plus efficace de la sécrétion de glucagon.

Anwesenheit von Pancreasglucagon im portalen Plasma von menschlichen Neugeborenen. Verschiedenartigkeiten in der Insulin- und Glucagonantwort nach Glucose zwischen normalen Kindern und Kindern diabetischer Mütter

Zusammenfassung. Menschliche Neugeborene wurden während der ersten Lebensstunden untersucht. Blutglucose, portales Plasmainsulin und Glucagon wurden sowohl in regulären Abständen bis zu 24 Std nach der Geburt als auch während einer intravenösen Glucose. belastung in der 24. Std untersucht. - Eine Substanz mit den immunologischen Charakteristika von Pancreasglucagon wurde im portalen Plasma sowohl von normalen Kindern als auch von Kindern diabetischer Mütter gefunden. Die intravenöse Glucosebelastung hat weder bei den normalen Neugeborenen noch bei den Kindern diabetischer Mütter das Plasmaglucagon unterdrückt. Im Vergleich zu den Kindern diabetischer Mütter wurden beiden normalen Neugeborenen in der späten Phase der intravenösen Glucosebelastung höhere Plasmaglucagonwerte beobachtet. Portales Plasmainsulin war bei den Kindern diabetischer Mütter sowohl nach 24 Std als auch während der ersten Phase des intravenösen Glucosetoleranztests erhöht gefunden. worden. - Es wird die Hypothese vorgeschlagen, daß das Verhalten der Unterschiede in der Glucagonsekretion möglicherweise eine Folge des relativen Hyperinsulinismus der Kinder diabetischer Mütter sei, welcher der Glucose den Eintritt in die Zelle durch Insulin erleichtert und so eine effektvollere Glucagonverminderung erlaubt.

Key words: hypoglycemia, glucagon, neonate, intravenous glucose, hyperinsulinism, diabetes, pancreatic $\alpha$-cell, diabetic mother, portal plasma.

\section{Introduction}

Studies on the physiology of glucagon have been hampered by major difficulties in the development of a sensitive and specific assay procedure (see Luyckx and Lefebvre, 1970). This undoubtedly explains the total

* Chargé de Recherches du Fonds National de la Recherche scientifique, Belgium. lack of data on the regulation of glucagon secretion in the newborn. This paper provides preliminary results indicating, for the first time, that circulating pancreatic glucagon is present in the portal plasma of the human neonate. It also reveals a distinct difference in the glucagon response to an intraportal glucose load, between normal infants and infants from diabetic mothers. 


\section{Material and Methods}

Thirteen normal neonates and five infants from diabetic mothers (IDM) were studied during the first $24 \mathrm{~h}$ after birth. The principal characteristics of the children and mothers are summarized in Table 1.

In all infants, a catheter was introduced into the portal vein, via the umbilical vein, in order to perform blood sampling and glucose infusion. In every case, the location of the catheter in the portal vein was verified radio. graphically. Throughout the $24 \mathrm{~h}$ study period, no oral feeding was permitted. In 7 of the normal infants and in 4 of the IDM, portal blood glucose and portal plasma insulin and glucagon levels were determined 6,12, 18 and $24 \mathrm{~h}$ after birth. In addition, in 7 of the normal infants and in all the IDM an intraportal glucose load $(1 \mathrm{~g} / \mathrm{kg}$ BW) was administered at the 24 th hour after birth. Portal blood glucose and portal plasma insulin and glucagon

Table 1

\begin{tabular}{|c|c|c|c|}
\hline Infant & $\begin{array}{l}\text { Birth } \\
\text { weight }\end{array}$ & Mother & Delivery \\
\hline M. $0^{\pi}$ & 3150 & normal & vaginal at term \\
\hline Bi. G. Â & 40 & norn & aginal at term \\
\hline M. & 3300 & moderate toxemia & vaginal at term \\
\hline 3r. G. $\sigma^{*}$ & 3000 & normal & vaginal at term \\
\hline L. $\quad$ q & 4330 & normal & vaginal at term \\
\hline M. B. 9 & 3400 & moderate toxemia & vaginal at term \\
\hline B. L. 운 & 3450 & normal & vaginal at term \\
\hline B. F. $\approx$ & $\mathbf{3 5 0 0}$ & norn & vaginal at term \\
\hline C. G. \& & 2950 & norr & $\begin{array}{l}\text { Caesarian sec- } \\
\text { tion at term }\end{array}$ \\
\hline S. 9 & 3110 & norn & term \\
\hline M. ठే & 3800 & nor & vaginal at term \\
\hline T. A. 운 & 2450 & normal & vaginal at term \\
\hline R. M. J & $\mathbf{3 0 0 0}$ & normal & vaginal at term \\
\hline G. A. 우 & 3450 & $\begin{array}{l}\text { mild diabetes } \\
\text { ed by diet alc }\end{array}$ & vaginal at term \\
\hline S. 우 & 4700 & $\begin{array}{l}\text { gestational diabetes } \\
\text { treated by diet alone }\end{array}$ & t term \\
\hline G. & 4500 & $\begin{array}{l}\text { mild diabetes treat- } \\
\text { ed by diet alone }\end{array}$ & serm \\
\hline M. V. P & 3700 & $\begin{array}{l}\text { insulin treated } \\
\text { diabetes }\end{array}$ & erm \\
\hline V.C. ठै & 4350 & $\begin{array}{l}\text { gestational diabetes } \\
\text { treated by diet alone }\end{array}$ & $\begin{array}{l}\text { Caesarian sec- } \\
\text { tion at term }\end{array}$ \\
\hline
\end{tabular}

levels were assayed before and at several intervals (see Tables) after the glucose load. Blood glucose was determined enzymatically (Huggett and Nixon, 1957) plasma insulin by radioimmunoassay (Hales and Randle, 1963) and plasma glucagon by an immunoassay using rabbit antiglucagon serum (final dilution 1/1800) $15 \mathrm{pg} /$ tube of $131 \mathrm{I}$-labelled glucagon, pork glucagon as a standard and a charcoal separation of antibody-bound and free hormone (Leclercq-Meyer et al., 1970). The antisorum used showed a weaker affinity for a total gut extract than for pancreatic glucagon, which classes it as "partially discriminant" (Heding, 1972).

The sensitivity and reproducibility of standard-curves for this type of assay are illustrated in Fig. 1. Within one assay series, and using duplicate determinations, $12.5 \mathrm{pg}$ of glucagon per tube $(125 \mathrm{pg} / \mathrm{ml})$ caused a significant decrease $(8.2 \%)$ of the percentage of labelled glucagon bound to the antibody $(p<0.01)$. The accuracy of the method for values between 0 and $500 \mathrm{pg} / \mathrm{ml}$ is $6.7+1.5$ (S.E.M.) \% (duplicates on 20 random determinations).

\section{Results}

1. The assay system used in this study demonstrated the presence of a material reacting with glucagon antibodies in the portal plasma of both normal neonates and IDM. The dilution curve of this immunoreactive material was perfectly parallel to that of the crystallized pancreatic glucagon used as a standard (Fig. 2), which strongly suggests that the material is pancreatic in origin. The portal plasma glucagon values obtained during the first $24 \mathrm{~h}$ of life are summarized in Table 2. As shown in this table, the values in normal

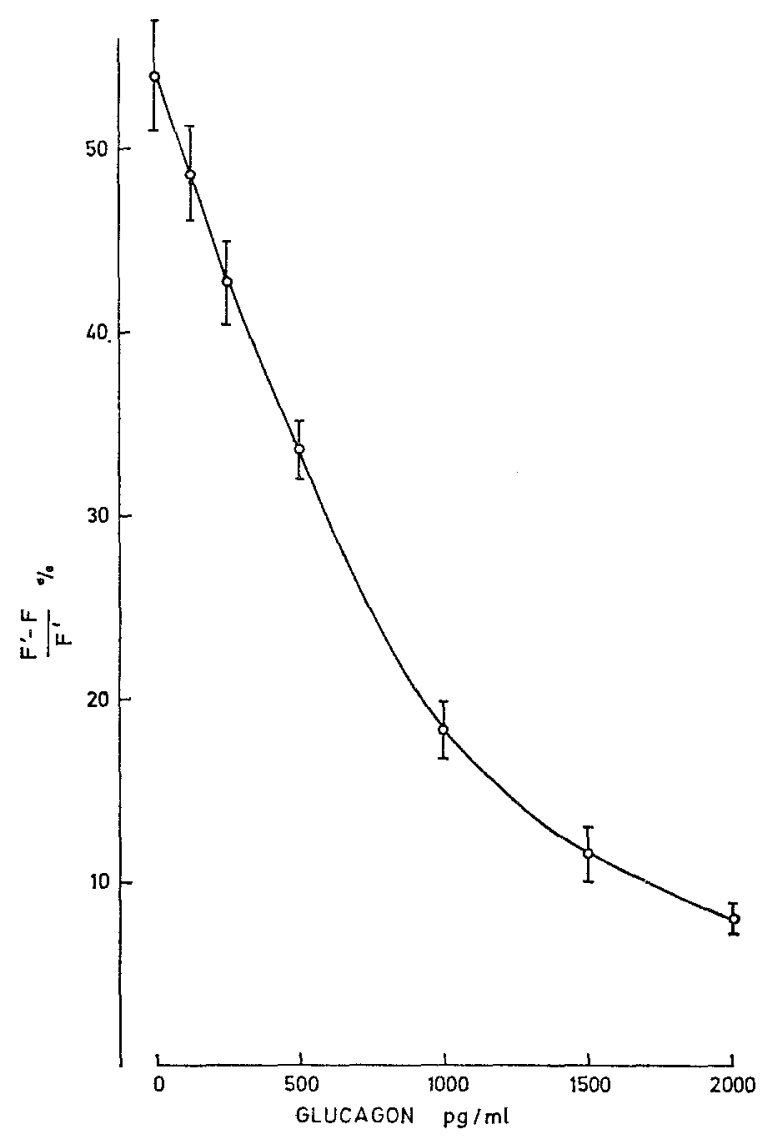

Fig. 1. Mean of 8 successive standard curves performed during a 4 month period. Comparison of paired values for zero and $125 \mathrm{pg} / \mathrm{ml}(\mathbf{1 2 . 5} \mathrm{pg} /$ tube) reveals a highly significant difference $p<0.001$. $\mathrm{F}^{\prime}$ corresponds to the amount of radioactivity bound to charcoal in the absence of antiserum and $\mathrm{F}$ to the amount of radioactivity bound to charcoal in the presence of antiserum and various concentrations of crystalline glucagon or plasma

infants ranged from 290 to $4800 \mathrm{pg} / \mathrm{ml}$ and, in every case but one a distinct rise was observed over the first few determinations. In 2 of the 4 IDM, much higher figures were obtained. The means were $1460 \pm 325$ $\mathrm{pg} / \mathrm{ml}$ (S.E.M.) for the normal infants and $3750 \pm$ $1750 \mathrm{pg} / \mathrm{ml}$ (S.E.M.) for the IDM. This difference is not, however statistically significant $(p<0.1)$. In contrast, portal plasma insulin is significantly higher 
at the 24 th $\mathrm{h}$ in IDM: $74.5 \pm 11.7(n=6)$ versus $37.2 \pm 2.4(n=4) \mu \mathrm{U} / \mathrm{ml}(p<0.02)$.

2 . The glucose assimilation constant (K) after intravenous glucose load was calculated according to Conard (1955). The $K$ value was significantly higher $(1.86 \pm 0.27)$ in the IDM than in the normal neonates $(1.19 \pm 0.13 ; p<0.05$ ) (Table 3 ).
4. Data on portal plasma glucagon, before and after intraportal glucose are given in Table 5. In the normal newborn, portal plasma glucagon concentrations changed only slightly and insignificantly during the first $30 \mathrm{~min}$ of the test. This was also true for IDM. Subsequently, an increase to $317 \%$ at the 60 th min and $834 \%$ at the 90 th min was noted in normal infants.

Table 2. Portal vein plasma glucagon and blood glucose values in the newborn

\begin{tabular}{|c|c|c|c|c|c|c|c|c|c|}
\hline \multirow[b]{2}{*}{ Hour } & \multicolumn{4}{|c|}{ Normal mother } & & \multicolumn{4}{|c|}{ Diabetic mother } \\
\hline & 06 & 12 & 18 & 24 & & 06 & 12 & 18 & 24 \\
\hline \multirow[t]{3}{*}{ T. M. } & 920 & 1050 & & 850 & G. A. & & 520 & 510 & 620 \\
\hline & 34 & 30 & & 38 & & & 88 & 100 & 88 \\
\hline & 50 & 52 & & 60 & & & 48 & 48 & \\
\hline \multirow[t]{3}{*}{ Bi. G. } & 540 & & 710 & 610 & R. S. & 990 & 380 & 590 & 530 \\
\hline & 43 & & 75 & 28 & & 46 & 27 & 52 & 50 \\
\hline & 71 & & 114 & 60 & & 40 & 10 & 10 & 60 \\
\hline \multirow{3}{*}{ C. $\mathbf{M}$. } & 290 & 600 & & 560 & L. G. & $>19550$ & 1980 & 2610 & 2020 \\
\hline & 34 & 38 & & 30 & & 130 & 120 & 115 & 100 \\
\hline & 30 & 91 & & 76 & & 25 & 48 & 40 & 61 \\
\hline \multirow[t]{3}{*}{ Br. G. } & & 410 & 510 & 320 & M. V. & 5070 & 19960 & 2470 & 2170 \\
\hline & & 33 & 28 & 29 & & 140 & 115 & 77 & 60 \\
\hline & & 74 & 72 & 60 & & 66 & 28 & 10 & 32 \\
\hline \multirow{3}{*}{ S. I. } & 2060 & 3040 & 960 & 200 & \multirow{9}{*}{\multicolumn{5}{|c|}{$\begin{array}{l}\text { For each subject, the first figure corre- } \\
\text { sponds to glueagon concentrations (pg/ } \\
\text { ml of portal plasma), the second to } \\
\text { portal plasma insulin ( } \mu U / \mathrm{ml}) \text { and the } \\
\text { third to portal blood glucose concentra- } \\
\text { tions (mg \%) }\end{array}$}} \\
\hline & 80 & 60 & 54 & 46 & & & & & \\
\hline & 86 & 76 & 86 & 81 & & & & & \\
\hline \multirow[t]{3}{*}{ M. $\mathbf{B}$. } & & 570 & & 1250 & & & & & \\
\hline & & 50 & & 42 & & & & & \\
\hline & & 86 & & 99 & & & & & \\
\hline \multirow[t]{3}{*}{ B. L. } & & 4800 & 4800 & 4080 & & & & & \\
\hline & & 42 & 36 & - & & & & & \\
\hline & & 65 & 70 & ro & & & & & \\
\hline
\end{tabular}

\section{Anti serum PVP $8 \quad 1 / 1800$ final \\ 13i I Glucagon $15 \mathrm{pg} /$ tube 28.05.71}
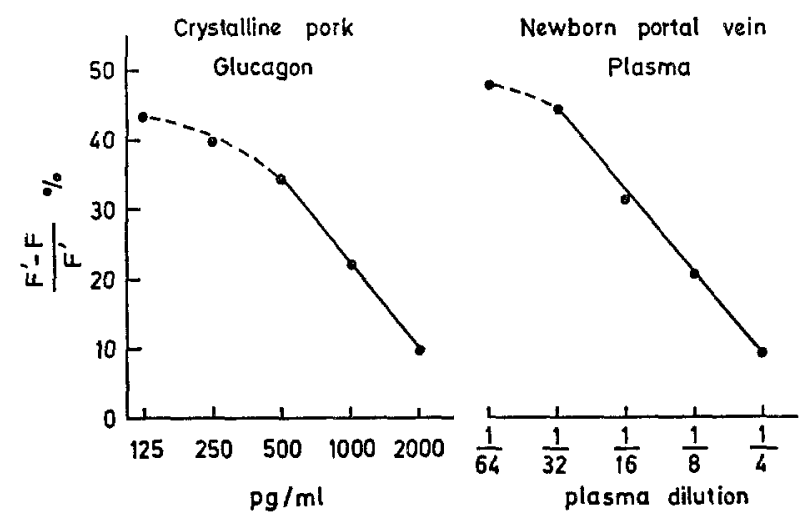

Fig. 2. Dilution slopes of crystalline pork glucagon (on the left) and of a newborn portal vein plasma (on the right). $F^{\prime}$ and $F$ see legend to Fig. 1

3. Table 4 illustrates the variations in portal plasma insulin after intraportal glucose. As reported in details elsewhere (Falorni et al., in press), basal portal plasma insulin was significantly higher in IDM; initial insulin response to glucose was markedly enhanced in IDM, statistically higher figures being recorded at $+1,+3$, +5 and $+10 \mathrm{~min}$.
This pattern was not observed in 4 of the 5 IDM who, in contrast, showed a decrease in portal glucagon. Comparison of pooled values measured at the 60 th and 90 th min of the test revealed a statistically significant difference between controls and IDM: $5020 \pm 1647$ versus $673 \pm 99 \mathrm{pg} / \mathrm{ml}$ (mean \pm S. E. M.) respectively $(p<0.05)$.

\section{Discussion}

The portal plasma of human neonates contains a material that reacts with glucagon antibodies. Dilution curves of this material are identical to those of crystallized pancreatic glucagon, arguing strongly in favour of its pancreatic origin. The dilution curves of human gut extracts are (indeed) known to differ from those of pancreatic extracts or crystallized glucagon (Samols et al., 1966) when using the so-called "partially discriminant" antisera (Heding, 1972). The absence of detectable amounts of gut GLI in newborn portal vein plasma might be related to the fact that oral glucose is presumably the major factor mobilizing gut "glucagonlike-immunoreactivity" (GLI) both in vivo (Samols et al., 1965) and in vitro (Luyckx and Lefebvre, 1969) and that, aside from the minimal amount ${ }^{1}$ of glucose

1 At the end of a normal pregnancy, the usual concentration of glucose in the amniotic fluid averages $30-35 \mathrm{mg} \%$. If the foetus is conceded to ingest $\pm 20 \mathrm{ml}$ 
ingested with the amniotic fluid, the gastro-intestinal tract of the infants studied had never been in contact with substantial amounts of glucose. Changes in the concentrations of portal plasma glucagon in normal neonates are relatively small, the usual trend being a slight increase between the 6 th and the 12 th or the 12th and the 18th hours. Although limited, these changes in plasma glucagon might be of importance in preliminary finding of very high plasma glucagon levels at certain moments in the portal blood of IDM. More striking are the differences between normal neonates and IDM in their endogenous glucagon response to a massive intravenous glucose load. Normal infants showed no inhibition of glucagon secretion in response to the glucose load. Moreover, cataglycemia ${ }^{2}$ was accompanied by a rise in plasma glucagon. In

Table 3. Portal blood glucose ( $m g \%$ ) after intraportal glucose $(1 \mathrm{~g} / \mathrm{kg} \mathrm{BW})$ in normal infants (upper part) and IDM (lower part)

\begin{tabular}{|c|c|c|c|c|c|c|c|c|c|}
\hline \multicolumn{2}{|c|}{ Time $(\min )$} & \multirow{2}{*}{$\frac{0}{81}$} & \multirow{2}{*}{$\frac{10}{285}$} & \multirow{2}{*}{$\frac{20}{268}$} & \multirow{3}{*}{$\begin{array}{l}30 \\
247 \\
246\end{array}$} & \multirow{2}{*}{$\frac{40}{176}$} & \multirow{2}{*}{$\frac{60}{125}$} & \multirow{2}{*}{$\frac{90}{85}$} & \multirow{2}{*}{$\frac{\mathrm{K}-10^{-2}}{1.00}$} \\
\hline \multirow[t]{9}{*}{ Normals } & B. F. & & & & & & & & \\
\hline & C. G. & 86 & 313 & 266 & & & 188 & 110 & 1.07 \\
\hline & P. S. & 66 & 465 & 320 & & \multirow[t]{5}{*}{209} & 171 & 95 & 1.50 \\
\hline & M. B. & 99 & 332 & 285 & 251 & & 180 & & 1.17 \\
\hline & R. M. & 52 & 342 & & 209 & & 132 & 95 & 0.91 \\
\hline & T. A. & 44 & 270 & 230 & 165 & & 105 & & 1.82 \\
\hline & Ro. Ma. & 109 & 275 & 218 & & & 154 & 123 & 0.85 \\
\hline & $\mathrm{m}$ & 77 & 326 & 265 & 224 & 193 & 151 & 102 & 1.19 \\
\hline & SEM & 9 & 25 & 15 & 16 & 17 & 12 & 7 & 0.13 \\
\hline \multirow[t]{8}{*}{ I.D.M. } & G. A. & 66 & 275 & 228 & 190 & 171 & 123 & 88 & 1.54 \\
\hline & R.S. & 60 & 295 & 254 & 195 & 175 & 150 & 86 & 1.73 \\
\hline & L. G. & 61 & 295 & 274 & 228 & 172 & 104 & 57 & 1.31 \\
\hline & M. V. & 32 & 247 & 199 & 152 & 114 & 57 & 38 & 2.88 \\
\hline & V.C. & 33 & 271 & 223 & 228 & & 104 & 62 & 1.82 \\
\hline & & 50 & 277 & 236 & 199 & 158 & 108 & 66 & 1.86 \\
\hline & SEM & 7 & 9 & 13 & 14 & 15 & 15 & 9 & 0.27 \\
\hline & & & & & & & \multicolumn{2}{|c|}{$p<0.05$} & $p<0.05$ \\
\hline
\end{tabular}

Table 4. Portal plasma insulin ( $\mu U / \mathrm{ml})$ after intraportal glucose ( $1 \mathrm{~g} / \mathrm{Kg} \mathrm{BW}$ ) in normal infants (upper part) and IDM (lower part)

\begin{tabular}{|c|c|c|c|c|c|c|c|c|c|c|c|}
\hline \multicolumn{2}{|c|}{ Time (min) } & \multirow{2}{*}{$\frac{0}{30}$} & \multirow{2}{*}{$\frac{1}{160}$} & \multirow{2}{*}{$\frac{3}{95}$} & \multirow{2}{*}{$\frac{5}{50}$} & \multirow{2}{*}{$\frac{10}{33}$} & \multirow{2}{*}{$\frac{20}{44}$} & \multirow{2}{*}{$\frac{30}{60}$} & \multirow{2}{*}{$\frac{40}{85}$} & \multirow{2}{*}{$\frac{60}{95}$} & \multirow{3}{*}{$\frac{90}{45}$} \\
\hline \multirow[t]{9}{*}{ Normals } & B. F. & & & & & & & & & & \\
\hline & C. G. & 32 & & 123 & 78 & 55 & 95 & 100 & & 230 & \\
\hline & P.S. & 31 & 220 & 140 & 85 & 70 & 200 & 280 & 360 & 280 & 100 \\
\hline & M. B. & 42 & 136 & 95 & 70 & 72 & 75 & 57 & & 105 & \\
\hline & R. M. & 30 & 240 & 90 & 52 & 90 & & 140 & & 170 & 62 \\
\hline & T. A. & 22 & 110 & 98 & 65 & 56 & 56 & 78 & & & 95 \\
\hline & Ro. Ma. & 40 & 265 & 110 & 60 & 90 & 115 & 130 & & 151 & 140 \\
\hline & $\mathrm{m}$ & 32 & 189 & 107 & 66 & 67 & 98 & 121 & & 172 & 92 \\
\hline & SEM & 3 & 25 & 7 & 5 & 8 & 23 & 29 & & 29 & 14 \\
\hline \multirow{7}{*}{ I.D.M. } & G. A. & 88 & 270 & 190 & 168 & 160 & 165 & 130 & 133 & 140 & 65 \\
\hline & R. S. & 50 & 500 & 200 & 120 & 220 & 58 & 60 & 62 & 120 & 70 \\
\hline & L. G. & 100 & 740 & 600 & 180 & 130 & 134 & 120 & 200 & 190 & 80 \\
\hline & M. V. & 60 & 560 & 390 & 260 & 440 & 280 & 320 & 320 & 130 & 80 \\
\hline & V. C. & 20 & 560 & 480 & 155 & 137 & 142 & 112 & & 255 & 90 \\
\hline & $\mathbf{m}$ & 64 & 526 & 372 & 177 & 217 & 156 & 148 & 179 & 167 & 77 \\
\hline & SEM & $\begin{array}{c}14 \\
p<0.05\end{array}$ & $\begin{array}{c}76 \\
p<0.01\end{array}$ & $\begin{array}{c}80 \\
p<0.01\end{array}$ & $\stackrel{23}{p<0.001}$ & $\begin{array}{c}58 \\
p=0.02\end{array}$ & 36 & 45 & 55 & 25 & 4 \\
\hline
\end{tabular}

regulating liver glycogenolysis and gluconeogenesis during total starvation. It should be recalled in this connexion that both human (Cornblath et al., 1958; de Meyer, 1968) and rat (Girard and Bal, 1970) newborn liver do respond to glucagon by increasing their glucose output. It is too early to speculate about our of amniotic fluid per hour, the amount of glucose thus ingested could not exceed $6-7 \mathrm{mg} / \mathrm{h}$, i.e. $140-170 \mathrm{mg} /$ day (Assali et al., 1968). contrast, compared to normal infants, plasma glucagon was significantly lower after exogenous glucose in IDM. In view of the recent data (Unger et al., 1970) suggesting that the entry of glucose into the $\alpha$ cell is an insulin-dependent process and the accepted fact, also confirmed here, that IDM have higher plasma

2 The term "cataglycemia" is used to characterize a decline in blood glucose during a given time, without necessarily reaching hypoglycemic values. 
insulin levels than normal neonates (Gentz et al., 1967; Pedersen, 1968; Falorni et al., in press) (as evidenced here also by the $K$ values of the two groups), it is tempting to speculate that the absence of cataglycemia-induced glucagon secretion in the IDM might result from the relative hyperinsulinism facilitating glucose entry into the $\alpha$ cells. This hypothesis however remains to be demonstrated.
7. Girard, J., Bal, D.: Effets du glucagon-zinc sur la glycémie et la teneur en glycogène du foie foetal du rat en fin de gestation. CR. Acad. Sc. Paris 271, 777$779(1970)$.

8. Hales, C.N., Randle, P.J.: Immunoassay of insulin with insulin-antibody precipitate. Biochem. J. 88, $137(1963)$.

9. Heding, L.: Immunologic propertios of pancreatic glucagon: Antigenicity and Antibody Characteristics in Glucagon. Molecular Physiology, Clinical and

Table 5. Portal plasma glucagon (pg/ml) after intraportal glucose $(1 \mathrm{~g} / \mathrm{kg} \mathrm{BW}$ ) in normal infants (upper part) and IDM (lower part)

\begin{tabular}{|c|c|c|c|c|c|c|c|}
\hline Time $(\min )$ & & 0 & 10 & 20 & 30 & 60 & 90 \\
\hline \multirow[t]{8}{*}{ Normals } & B. F. & 733 & 695 & 749 & 802 & 894 & - \\
\hline & C. G. & 1864 & 2444 & 1123 & 1138 & 2169 & 8984 \\
\hline & P. S. & 6294 & 18211 & 5622 & 7578 & 14480 & - \\
\hline & M. B. & 1253 & 1146 & 1681 & 1940 & 1016 & - \\
\hline & R. M. & 412 & 336 & & 512 & 5072 & 4889 \\
\hline & T. A. & 2162 & 1883 & & 1756 & 2657 & \\
\hline & & 2120 & 4110 & 2293 & 2287 & 4381 & 6937 \\
\hline & SEM & 877 & 2837 & 1126 & 1081 & 2111 & 2048 \\
\hline \multirow{7}{*}{ I.D.M. } & G. A. & 619 & 550 & 428 & 571 & 405 & \\
\hline & R. S. & 527 & 512 & & 266 & 428 & 489 \\
\hline & L. G. & 2016 & 3346 & 1726 & 3285 & 1039 & \\
\hline & M. V. & 2169 & 825 & & 550 & 993 & \\
\hline & V.C. & 435 & 237 & & 679 & 618 & 741 \\
\hline & $\mathrm{m}$ & 1153 & 1094 & & 1070 & 696 & 615 \\
\hline & SEM & 385 & 570 & & 558 & 136 & 126 \\
\hline
\end{tabular}

Acknowledgements. We are indebted to Dr. R. Assan, Paris for the gift of PVP 8 antiglucagon antiserum used in this study. The financial support of the Fondation Médicale Reine Elisabeth is gratefully acknowledged. Mrs. C. Cartenstadt and Miss Claessens are thanked for their skilled technical assistance.

Requests for reprints should be adressed to Dr. A.S. Luyckx, Institut de Médecine, Université de Liège, 4000 Liege, Belgium.

\section{References}

1. Assali, N.S., Dilts, P.V. Jr., Plentl, A. A., Kirschbaum, T.B., Gross, S.J.: Physiology of the placenta, 185289 in Biology of Gestation, Vol. I. The Maternal Organism, p. 185, Assali, N.S. Editor. New-York and London: Academic Press 1968.

2. Conard, V.: Mesure de l'assimilation du glucose. Bases théoriques et applications cliniques. Acta gastroendocrinolog. Belgica 18, 803-845 (1945).

3. Cornblath, M., Levin, E.Y., Marquetti, E.: Studies of carbohydrate metabolism in the newborn. II. The effect of glueagon on the concentration of the capillary blood sugar in infants of diabetic mothers. Pediatrics 21, 855-892 (1958).

4. de Meyer, R.: La glycorégulation du nouveau-né. Acta Paediat. Belg. 22, 291 - 334 (1968).

5. Falorni, A., Fracassini, F., Massi-Benedetti, F., Amici, A.: Glucose metabolism, plasma insulin and growth hormone secretion in infants affected by erythoblastosis fetalis compared with newborns of normal and diabetic women. Pediatrics (in press).

6. Gentz, L., Lunell, N.O., Persson, P.O.B., Sterky, G.: Glucose tolerance in overweight babies and infants of diabetic mothers. Acta paediat. Scand. 56, 228-230 (1967). therapeutic Implications, Lefebvre, P.J. and Unger, R.H. Editors. Oxford: Pergamon Press 1972.

10. Huggett, A. S.G., Nixon, D.A. : Uso of glucose oxidase, peroxidase and O-dianisidin in the determination of blood and urine glucose. Lancet 1957 II, 368-370.

11. Leclercq-Meyer, V., Miahle, P., Malaisse, W.J.: Une méthode de dosage radioimmunologique du glucagon comportant une séparation par le charbon-dextran. Diabetologia 6, 121-129 (1970).

12. Luyckx, A. S., Lefebvre, P.J.: Release of glucagon or a glucagon-like inmunoreactive material by rat jejunum incubated in vitro; 884-886 in Protein and Polypeptide Hormones, Margoulies M. Editor. Excerpta Medica Foundation Amsterdam (1969).

13. - - Glucagon, 163-182 in Assay of Protein and Polypeptide Hormones, Van Cauwenberge, $H$. and Franchimont, P. Editors. Oxford: Pergamon Press. 1970.

14. Pedersen, L.M.: Glucose tolerance in newly born children of diabetic mothers. Acta paediat. Scand. 57, $460-461$ (1968).

15. Samols, E., Tyler, J., Marri, G., Marks, V.: Stimulation of glucagon secretion by oral glucose. Lancet 1965 II, $1257-1259$.

16. - - Megyesi, C., Marks, V.: Immunochemical glucagon in human pancreas, gut and plasma. Lancet $1966 \mathrm{I}, 727-729$.

17. Unger, R.H., Aguilar-Parada, E., Muller, W., Eisentraut, A.M.: Studies of pancreatic alpha cell function in normal and diabetic subjects. J. clin. Invest. $\mathbf{4 9}$, $837-847(1970)$.

$$
\begin{aligned}
& \text { Dr. P. Lefebvre } \\
& \text { Université de Liège } \\
& \text { Hopital de Bavière } \\
& \text { Institut de Medecine } \\
& \text { B-4000 Liège, Belgium }
\end{aligned}
$$

